\title{
STRUCTURAL CONTROLS ON MINERALIZATIONS AT ABU HARBA AREA, NORTH EASTERN DESERT, EGYPT
}

\author{
Soliman, M. A. ${ }^{1}$ Osman, A. F. ${ }^{2}$ Mahmoud, F. O. ${ }^{2}$ Dowidar, H. M. ${ }^{2}$ and El Sandouly, H. I. ${ }^{1}$ \\ 1 Nuclear Materials Authority, P.O. Box 530, Maadi, Cairo, Egypt. \\ 2 Geology Department, Faculty of Science, Ain Shams University.
}

\begin{abstract}
Abu Harba area is located in the North Eastern Desert (NED) which mainly covered by metavolcanics, Dokhan volcanics, metagabbro-diorite complex and younger granites. The detailed structural analysis of Abu Harba area indicate that shear stress trending NNE-SSW and NW-SE directions represent nearly the the Gulf of Aqaba and the Gulf of Suez trends. The lineaments in the area are multidirectional orientation with three main trends; ENE-WSW, NE-SW and E-W with less dominant trends represented by N-S, NNW-SSE and NW-SE directions.

The mineralizations of secondary uranium (uranophane, kasolite and betafite) in Abu Harba area seem to be lithologically and structurally controlled. The alkali feldspar granites in the area contain highly amounts of silica and alkalis, accessory minerals and iron oxides. On the other hand, the NE-SW lineaments in the study area allowed the hydrothermal solution that bear uranium minerals to infiltrate upwardly parallel faults and joint sets at the peripheral western part of G. Abu Harba alkali feldspar granites. As the faults are suitable places for the flow of hydrothermal solutions bearing mineralization. So, the mineralizations appear to be structurally controlled.
\end{abstract}

Keywords: Abu Harba; Metavolcanics; Dokhan volcanics; Syenogranites and Alkali feldspar granites; Radioactive minerals; Structural lineaments.

\section{INTRODUCTION}

Igneous rocks are considered to be the source of most uranium deposits when these deposits formed by the fluids during the crystallization of magma or when the primary content of uranium is redistributed by hydrothermal or meteoric solutions (Bohse et al., 1974). There is a relationship between the intensity and distribution of radioactivity, the lithology and structure pattern of younger granite at the studied area (Abd El-Hadi, 2006). Abu Harba area has affected by secondary structures represented by faults and joints. Both faults and joints have nearly compatible directional trends, indicating a genetic relation. The prevalent fault trends dissecting the study area with decreasing order in number are NE-SW, ENE-WSW and N-S as well as NNW-SSE and E-W (Abdel Hamid, 2013). Abu Harba granites are alkali feldspar granites with some low hills of syenogranites and characterized by the presence of secondary uranium minerals such as kasolite, uranophane and beta-uranophane (Waheeb, 2016).

Abu Harba area is located about $60 \mathrm{~km}$ north-west of Hurghada city and delineated by latitude $27^{\circ} 11^{\circ}$ $00^{\prime \prime}$ to $27^{\circ} 23^{\prime} 00^{\prime \prime}$ North and longitude $33^{\circ} 06^{\prime} 00^{\prime \prime}$ to $33^{\circ} 15^{\prime} 20^{\prime \prime}$ East which cover about $280 \mathrm{~km}^{2}\left(\mathrm{Fig}^{\circ}\right.$. 1). The investigated area is covered by the Neoproterozoic basement rocks. Abu Harba area is composed of granitic rocks intruded volcanic rocks with limited distribution of metagabbro-diorite complex and dissected by numbers of dykes.

\section{GEOLOGICAL SETTING}

Abu Harba area consists mainly of post-orogenic granites intruding island arc metavolcanics, Dokhan volcanics and limited areas of metagabbro-diorite complex. The post-granitic dykes and veins cut all the rock types representing last igneous manifestation in the study area (Fig. 2). 
Soliman, et al

Fig. 1: Location map and Landsat 8

(OLI/TIRS) image of the study area.
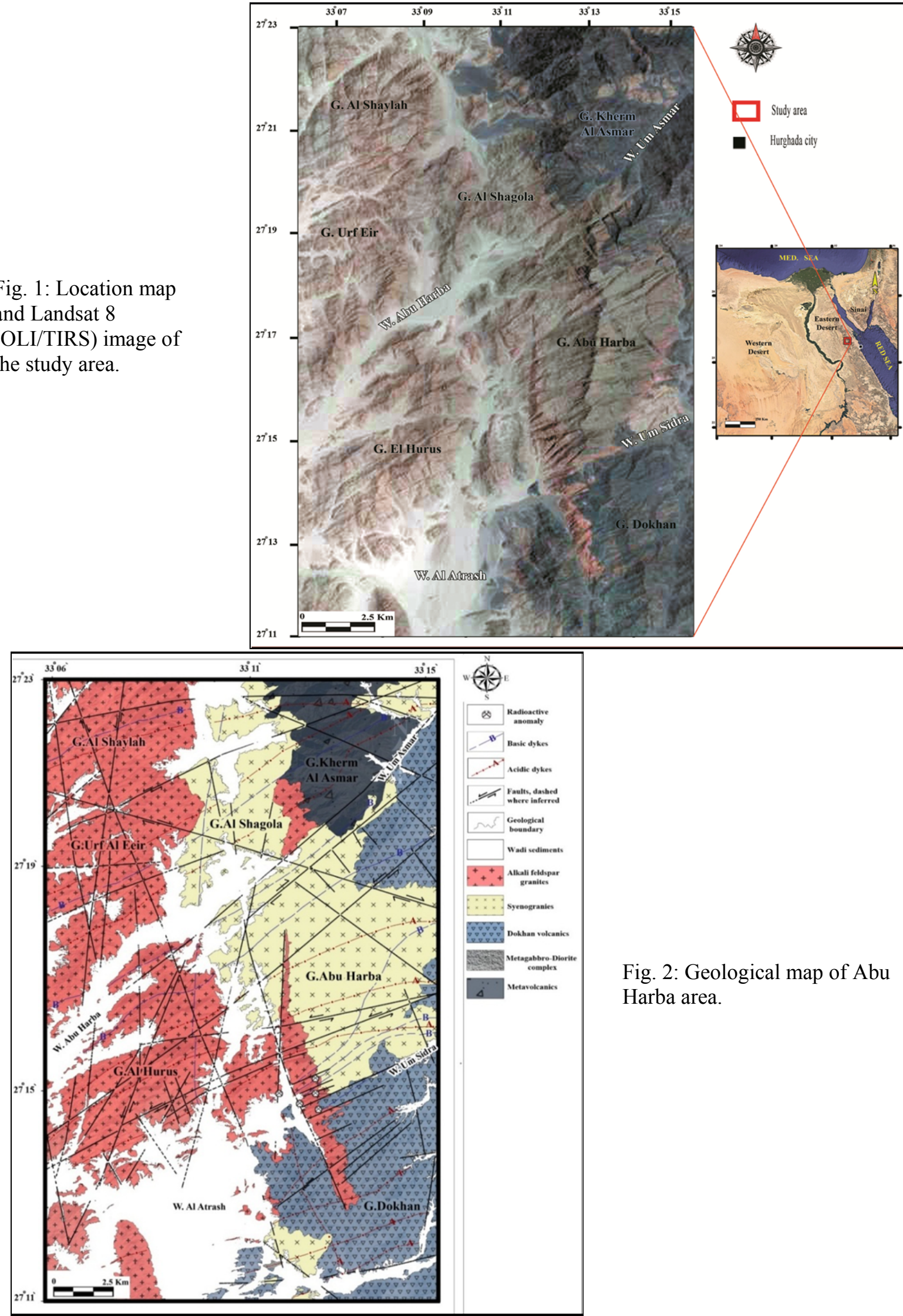

Fig. 2: Geological map of Abu Harba area. 
There is a relationship between the morphology and shape of the area with its geology and structure. Metavolcanics in the area show, compact and massive rocks surrounded conical high hills shaped younger granites. The Dokhan volcanics show rugged, jointed than granitic peaks which show low to medium hills except in some places shown more than $1000 \mathrm{~m}$ a.s.l.

The metavolcanics exposed at G. Kherm Al Asmar NE of the mapped area covers about $20 \mathrm{~km}^{2}$. They form highly elevated mountains reaching about $1550 \mathrm{~m}$ above sea level, rough topography with steep slopes. These metavolcanics intruded by the younger granites with sharp irregular contacts and traversed by post- granitic dykes trending NE-SW, ENE-WSW and E-W. Petrographically, the metavolcanics range in composition from metabasalts to meta-andesites, which commonly exhibit porphyritic textures. The regional metamorphism is within the greenschist facies. Radiometrically, these metavolcanics are not exceeding to $160 \mathrm{cps}$ with average $\mathrm{eU} 4.6 \mathrm{ppm}$.

The metagabbro-diorite complex in the study area is located at the eastern part of W. Al Atrash. These metagabbros appear as low hills with gentle slopes contacting with flow textures ignimbrite of Dokhan volcanics. The metagabbros are fractured, jointed and highly weathered and traversed by long back-bone acidic dyke. These rocks are equigranular, porphyroblastic in texture and they are essentially composed of calcic plagioclase and hornblende with subordinate amount of pyroxene. The radiometric studies of this complex show that these are not exceed $290 \mathrm{cps}$ with average eU $3.5 \mathrm{ppm}$.

The Dokhan volcanics are located at the eastern and southeastern parts of the mapped area and characterized by rough topography and sharp peaks reaching about $900 \mathrm{~m}$ (a.s.1) and intruded by G. Abu Harba younger granites with sharp intrusive contact. These volcanics traversed by numerous dykes and veins striking mainly NE-SW, ENE-WSW and E-W directions.

Petrographically, they include lava flows which subdivided into intermediate and acidic volcanic varieties as well as their pyroclastics, where the intermediate flows are characterized by andesitic rocks. On the otherwise, the acidic flows are mainly represented by rhyolite, rhyodacite and dacite. The radiometric studies revealed that these rocks not exceed $270 \mathrm{cps}$ with average eU $2.75 \mathrm{ppm}$.

The younger granites of the study are classified into syenogranites and alkali feldspar granites with gradually to sharp contact with surrounding volcanic rocks.

The syenogranites outcropping at most of G. Abu Harba and G. Al Shagola contacting gradually with the alkali feldspars granites and sharply with the surrounding volcanics. Syenogranites are more intensly fractured than the alkali feldspar granites and well jointed in all directions specially N-S, NE-SW and E-W directions and also cutted by one or more sets of faults mostly directed to the NE-SW. Petrographically, these granites are characterized by medium to coarse grained, grayish pink color, holocrystalline, equigranular and composed essentially of perthite, quartz, plagioclase and biotite, with minor amounts of hornblende, which displaying porphyritic texture. Syenogranites reach up to $340 \mathrm{cps}$ with average eU 8.2 ppm in the radiometric measurements.

Alkali feldspar granites outcropping at the western part of G. Abu Harba, G Al Hurus, G. Urf Al Eeir and G. Al Shaylah that recognized by high rough mountains with serrated peaks. Nevertheless they can resist the weathering and erosional processes more than syenogranites. These granites are cut by one or more sets of faults mostly directed to the NE-SW and traversed by numbers of dykes and veins with the direction of NE-SW and ENE-WSW. They are medium, to very coarse grained, grading into pegmatitic texture in some parts ranging in color from pale pink, pink to reddish pink. Petrographically, these rocks are similar to the syenogranites but distinguished by their high abundance of potash feldspar and quartz contents and of less content of plagioclase relative to syenogranites. They are consisting mainly of perthite and quartz as essentially minerals with subordinate plagioclase and displays hypidiomorphic equigranular texture. Biotite, muscovite, zircon, monazite, fluorite, apatite, allanite, sphene and iron oxides are accessories (Fig. 3). These granites has been affected by hydrothermal solutions especially along fault zones represented by hematitization, kaolinitization, silicification, flouritization and chloritization as well as epidotization which nearly responsible for the formation of secondary uranium mineralizations (Fig. $3 \mathrm{f})$. This type of granites documented the highest radiometric measurements up to $640 \mathrm{cps}$ with average eU 15.5 ppm. 
Fig. 3: Photomicrographs of alkali feldspar granites: a) Euhedral zircon with metamictized core and coated by iron oxide included in plagioclase, C.N, X20. b) Minute monazite crystal with pleochroic haloes included within perthite, C.N, X20. c) Fine allanite crystal associated with K- feldspar, C.N, X20. d) Rhombic-shaped crystal of sphene associated with quartz and feldspar. Muscovite flakes occur interstitial between perthite and quartz, C.N, X20. e) Iron oxides associated with zircon crystals, C.N, X10. f) Secondary uranium minerals stained with hematite and filling the interstitial spaces of perthite in altered alkali feldspar granites, C.N, X10.
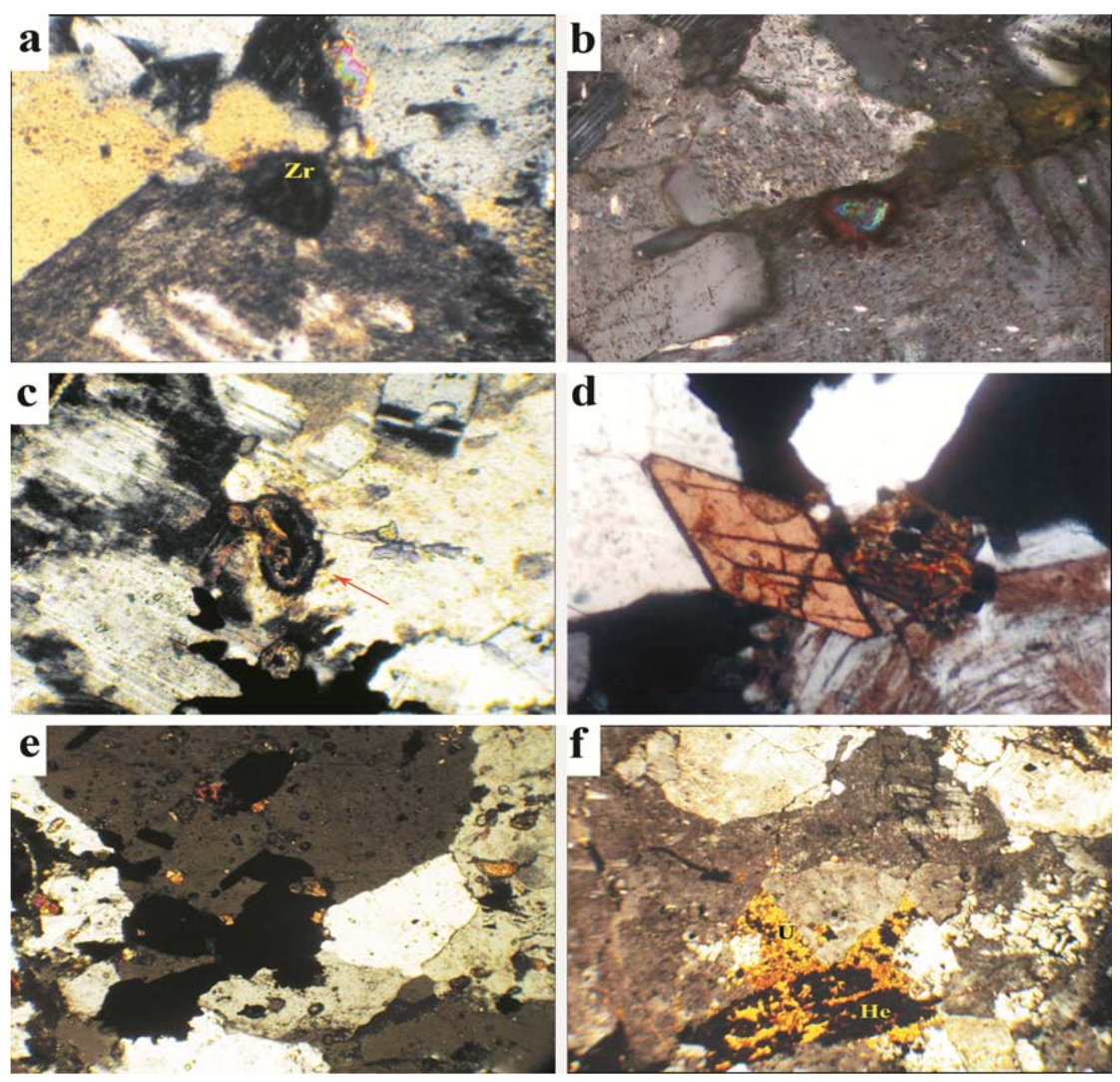

\section{STRUCTURAL SETTING}

The Neoproterozoic basement rocks in Egypt classified into three main domains which are the northern, central and the southern domain (Stern and Hedge, 1985). Abu Harba area located at the North Eastern Desert belonging to the northern domain that characterized by normal fault with trending NE-SW as well as strike slip ones (Abu Deif, 1992). This area also belong structurally to unstable shelf which characterized by NE-SW and E-W trends (Abdallah, 1999).

\section{Joint trend analysis}

Joints in Abu Harba area follow E-W, N-S and NE-SW directions. These trends subjected to intense structural deformation occurred by Tethyan regional trend (Said, 1962), Nubian regional trend (Meshref, 1990) and the major shear zone that separating the North Eastern Desert domain from the Central Eastern Desert (El Gaby et al., 1984) sequentially.

The mineralization hosted by the joints of the Abu Harba alkali feldspar granites and the associated alteration features represented by silicification, kaolinitization, flouritization and epidotization along these joints are mostly also directed N-S, NE-SW and E-W as obtained from the quantitative analysis of the field measurements.

Bucher (1920) derived a method for the derivation of the direction of shear stress affected the joints. This study includes detailed structural analysis for the uranium mineralized N-S, NE-SW and E-W joints in the alkali feldspar granites of Gabel Abu Harba in order to detect the direction of resolved shear sense of movement. All joint measurements are constructed as density-contoured lower hemisphere Schmidt stereogram of poles to joint planes by using contour diagram of the poles of joints, plotting the amount of dip and directions on the stereonet graph paper and then using this data on the WinTensor program to detect $\sigma 1$ (S1), $\sigma 2$ (S2) and $\sigma 3$ (S3) as hemisphere Schmidt stereogram of poles to detect the sense of movement stress.

By applying this method on each type of rock, it found that: 
The sense of movement at the metavolcanics is tensile stress affecting NNW-SSE direction (Fig. 4a). The sense of movement at the metagabbros is tensile stress affecting NNE-SSW direction (Fig. 4b). The sense of movement at the Dokhan volcanics is tensile stress affecting NNW-SSE direction (Fig. 4c). The sense of movement at the syenogranites is shear stress affecting NNE-SSW compressive stress and NWSE tensile stress (Fig. 4d). The sense of movement at the alkali feldspar granites is shear stress affecting NNE-SSW compressive stress and NW-SE tensile stress (Fig. 4e). So, the sense of movement at the total rocks is shear stress affecting NNE-SSW compressive stress and NW-SE tensile stress (Fig. 4f).

Based on that, the detailed structural analysis for the joints of Abu Harba area especially the mineralized one indicate that the sense movement of the stress is shear stress affecting NNE-SSW and NW-SE directions which representing nearly the direction of the Gulf of Aqaba and the Gulf of Suez. The direction of shear stress in the mineralized joints is responsible for the localization and distribution of radioactive minerals in Gabel Abu Harba alkali feldspar granites could be initiated due to the effect of the youngest extensional phase of Red Sea- Gulf of Suez region rifting which nearly the same tectonic that occurred at G. Gattar (Waheeb, 2017). So, the relation between the localization and distribution of radioactive minerals of G. Abu Harba with Red Sea-Gulf of Suez rifting might be very great.

Fig. 4: Hemisphere Schmidt stereogram of poles to joint planes and the inferred stress regimes.

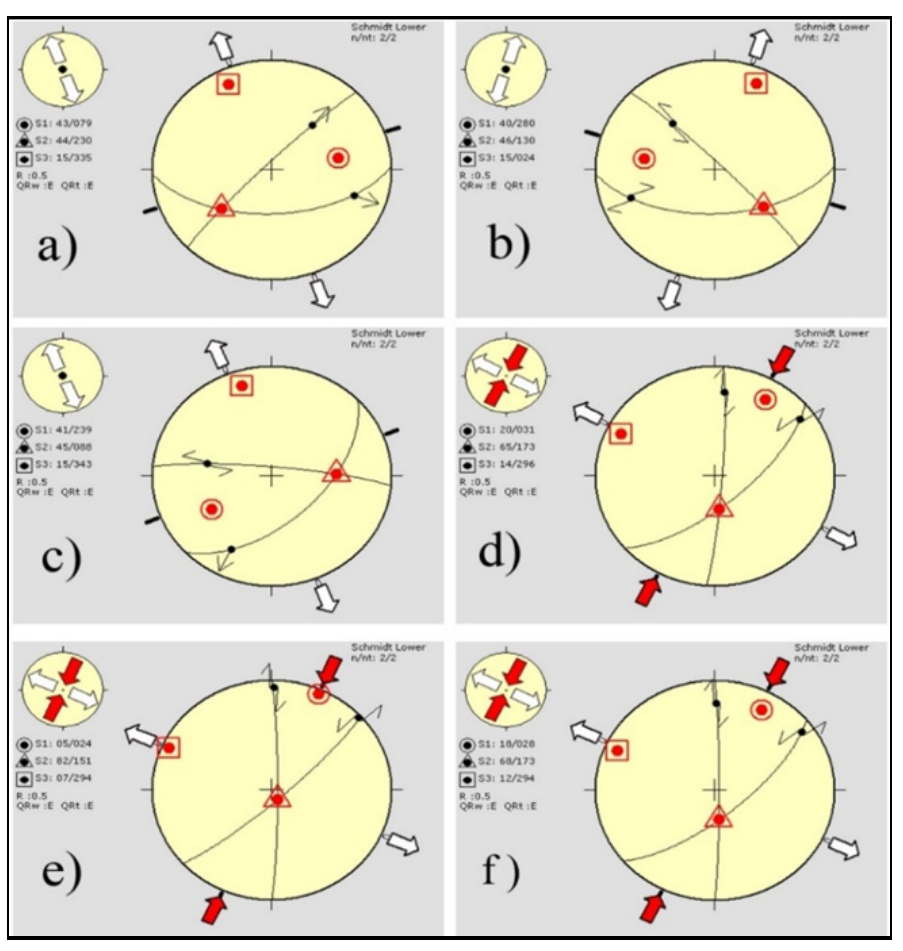

\section{Fault trend analysis}

In the study area, faults were measured with lengths about 267 kilometers in the different kind of rocks which statistically treated and showing at rose diagram (Fig. 5). Abu Harba area as a whole suffered from two phases of deformation which could be summarized as the following:

\section{First phase structures}

The first phase of deformation that affected Abu Harba area is the compression force where maximum compression $(\sigma 1)$ is directed N-S causing the formation of two conjugate shear fractures sets that trending NNE-SSW sinistral faults and NNW-SSE dextral faults (Fig. 6).

\section{Second phase structures}

This phase occur by the rotation in the axis of stress of movement occur due to change in the tectonic phase producing compression force where new $\sigma 1$ maximum compression axis is directed $\mathrm{N} 70 \mathrm{E}$ 
producing two recent conjugate shear fractures (ENE-WSW sinistral and WNW-ESE dextral faults) causing dislocation of two previously NNE and NNW faults (Fig. 6).

It's worth to mention that these structure phases are nearly the same to that happened in G. Gattar batholith which located at the south of the study area (Khamis, 1995).

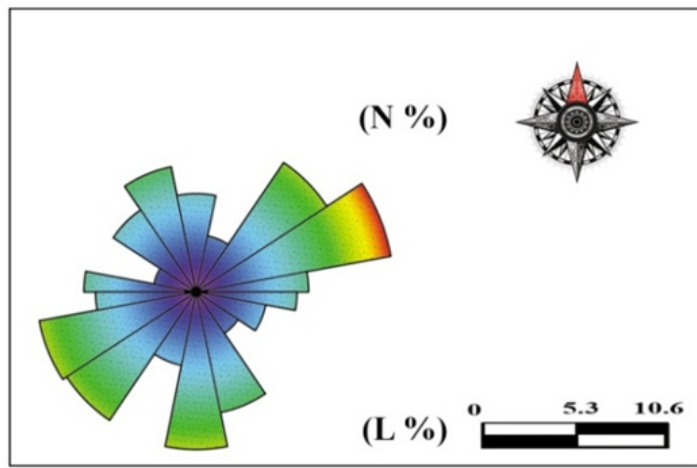

Fig. 5: Rose diagram showing the trends of faults that measured in the study area according to their number (N\%) and length (L\%).

Fig. 6: Evolution of the Structures of Abu Harba area through time

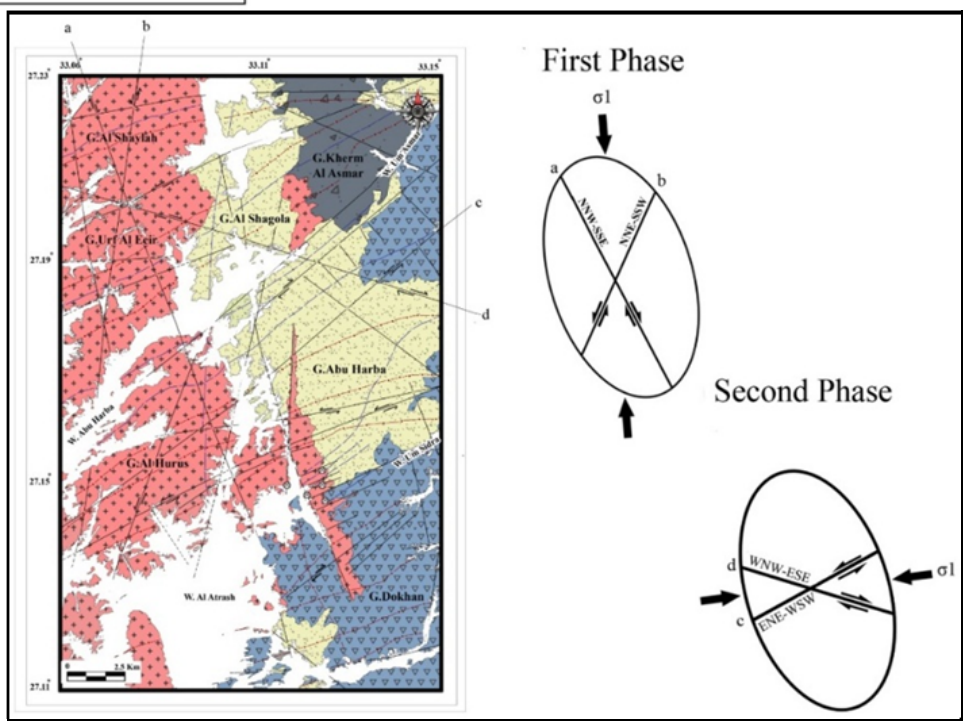

\section{Surface lineament analysis}

Lineaments on aerial photos or/and Landsat images may be related to zones of weakness in the Earth crust and probably represent fracture traces (Sabins, 1997). The technique of observing and mapping lineaments from aerial photographs began as early as 1928, (Lattman, 1958). Surface lineament could be defined as a mappable, simple or composite linear feature of surface whose parts are aligned in a rectilinear or slightly curvilinear relationship and which differ from the pattern of adjacent features and presumably reflects some sub-surface phenomenon (O'Leary et al., 1976).

In the study area, structural lineaments either fractures, faults, joints or dykes are showing heterogeneity in their trend pattern of deformation reflecting a complex tectonic history accumulated since Precambrian. The identified surface lineaments in Abu Harba area are demonstrated on (Fig. 7\&8). These surface lineaments are document multidirectional orientations with three main trends which are the following; ENE-WSW representing the first main trend with the percentage of frequency of about $30.9 \%$ and their lengths about $37.9 \%$. The second predominant trend is NE-SW demonstrating about $28.2 \%$ of the total numbers of the area with lengths of about $31 \%$. The third common trend of the study area is E-W direction illustrating about $15.8 \%$ of the total frequency with the total lengths of about $13.8 \%$. The main trends of these lineaments are nearly the same trends of the studied joints, faults and dykes which mean all of these structural lineaments are structurally affecting by Qena-Safaga regional trend (Youssef, 1968) and major trends of Tethyan regional trend (Said, 1962). 


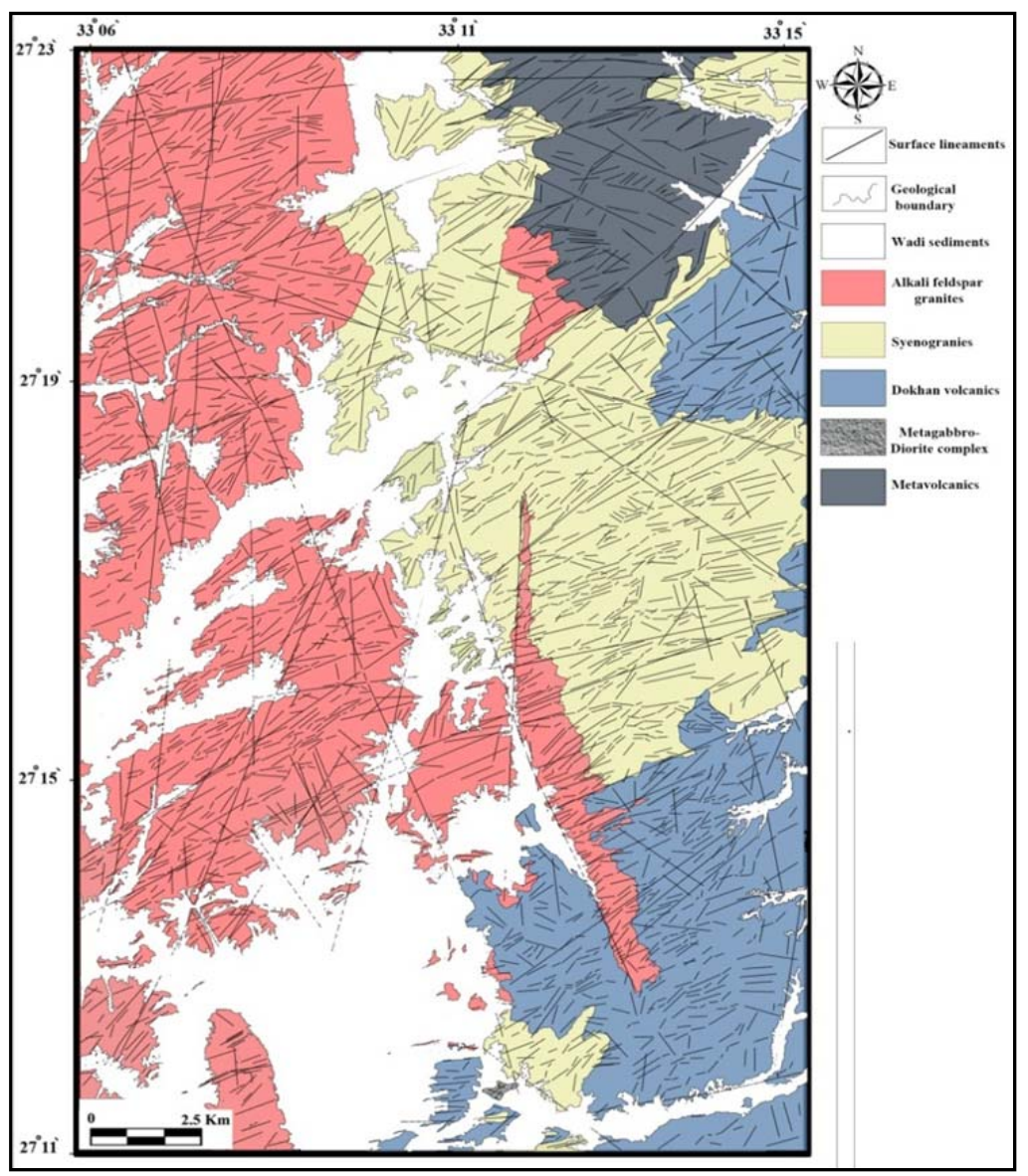

Fig. 7: Lineament map showing the distribution of 3125 lines in the study area

Fig. 8: Rose diagrams showing the main trends of both number $(\mathrm{N})$ and length $(\mathrm{L})$ proportions of surface lineaments in the whole study area.

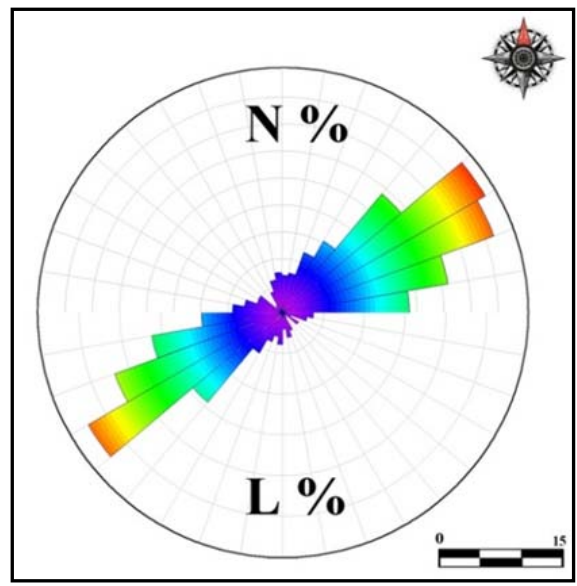

The previous results matched the lineament maps with the detailed structural field measured elements in the area of study. Highly faulting played an important role in facilitating the alteration processes through the circulation of both hydrothermal solutions and/or meteoric water causing enrichments in large radio-elements like uranium and thorium. This explains the obvious relation between the lineament density and the presence of radioactive potentialities along with degree of alteration that will be discussed in detail later.

\section{RADIOACTIVITY AND MINERALIZATION}

The radiometric survey of the rocks of Abu Harba area is carried out by means of Portable RS-230 gamma $(\gamma)$ ray. This instrument gives the field radioactivity of the rocks in terms of count per second (CPS). Before the performance of the field measurements the portable $\gamma$-rays detector was calibrated in the 
labs of the Exploration Division on Nuclear Materials Authority of Egypt using Gad-6 spectral $\gamma$-rays detector for comparison. Intensive gamma ray survey is performed on the various rock types in the studied area for detecting the surface concentrations of the radioelements. During this survey, particular care was taken to the alkali feldspar granite where the uranium mineralization is expected to found, especially at its altered parts and along the tectonized zones. These recorded gamma readings were statistically treated (Table 1).

Thirty-four samples from the various rock types were selected for laboratory measurements. Their content of $\mathrm{U}$, Th, Ra and $\mathrm{K}$ were measured by using "Bicron scintillation detector Na-1 (TI) 76×76 mm with multi-channel analyzer" to determine radiometrically their eU, eTh, eRa contents in parts per million (ppm) and K (\%) in Nuclear Materials Authority Lab. The younger granites either syeno- or alkali feldspar granites show high content of radioelements (eU and $\mathrm{eTh}$ ) relative to other rocks. In fact, Th is considered to be a relatively immobile element which mean it resists redistribution by the chemical weathering and alteration processes to a great extent (Abdel Ghani et al., 2003). These results are illustrated (Table 2).

Table 1: Summary of statistical values of total gamma radioactivity measurements (cps) in Abu Harba area.

\begin{tabular}{|l|c|c|c|}
\hline \multirow{2}{*}{ Rock Type } & \multicolumn{3}{|c|}{ Field measurements (cps) } \\
\cline { 2 - 4 } & Min. & Max. & Av. \\
\hline Basic dyke & 120 & 180 & 155 \\
\hline Acidic dyke & 135 & 310 & 195 \\
\hline Pegmatites & 370 & 520 & 450 \\
\hline Alkali feldspar granites & 220 & 650 & 380 \\
\hline Syenogranites & 170 & 350 & 250 \\
\hline Dokhan volcanics & 120 & 270 & 190 \\
\hline Metagabbro-Diorite Complex & 270 & 290 & 280 \\
\hline Metavolcanics & 110 & 160 & 145 \\
\hline
\end{tabular}

Table 2: Results of radiometric analyses of some samples collected from Abu Harba area.

\begin{tabular}{|c|c|c|c|c|c|c|c|c|c|c|c|c|c|}
\hline \multirow{3}{*}{ Rock Type } & \multicolumn{13}{|c|}{ Laboratory measurements (ppm) } \\
\hline & \multicolumn{3}{|c|}{$\mathrm{eU}$} & \multicolumn{3}{|c|}{ eTh } & \multirow[b]{2}{*}{$\mathrm{eTh} / \mathrm{eU}$} & \multicolumn{3}{|c|}{$\mathrm{eRa}$} & \multicolumn{3}{|c|}{$\mathrm{K} \%$} \\
\hline & Min. & Max. & Av. & Min. & Max. & Av. & & Min. & Max. & Av. & Min. & Max & Av. \\
\hline Basic dykes & 1 & 4 & 2.3 & 4 & 5 & 4.3 & 1.87 & 2 & 2 & 2 & 1.13 & 1.77 & 1.37 \\
\hline Acidic dykes & 3 & 5 & 4.4 & 5 & 15 & 11 & 2.5 & 3 & 11 & 6 & 2.35 & 2.94 & 2.61 \\
\hline Pegmatites & 6 & 10 & 8 & 16 & 21 & 19 & 2.38 & 3 & 6 & 4 & 2.48 & 3.17 & 2.86 \\
\hline Alkali feldspar $g$. & 11 & 24 & 15.5 & 33 & 47 & 39.6 & 2.55 & 4 & 11 & 7.7 & 2.66 & 3.33 & 2.92 \\
\hline Syenogranites & 2 & 13 & 8.2 & 5 & 27 & 17 & 2.07 & 3 & 7 & 4.6 & 1.91 & 3.32 & 2.83 \\
\hline Metagabbros & 1 & 4 & 2.75 & 3 & 5 & 4.25 & 1.55 & 2 & 11 & 4.25 & 0.94 & 2.56 & 1.4 \\
\hline Dokhan $v$. & U.D & 4 & 3.5 & 4 & 12 & 8.3 & 2.37 & 2 & 3 & 3.5 & 0.71 & 1.92 & 1.44 \\
\hline Metavolcanics & 2 & 6 & 4.67 & 3 & 5 & 4 & 0.86 & 3 & 4 & 3.5 & 0.84 & 1.46 & 1.24 \\
\hline
\end{tabular}

U.D under the limit of detection

The uranium mineralization are restricted to reactivated shear zones which characterized by intense fracturing, closely spaced jointing pattern, medium-grained and hydrothermally altered rocks. Visible secondary uranium mineralization of bright yellow colors are recorded on the various levels of elevation. The uranium mineralizations occur in different styles as stains or filling the micro-fractures of the alkali feldspar granites. Anomaly No.1 with 5500 ppm, is located at the southwestern part of G. Abu Harba alkali feldspar granites. It is discovered along a major fault zone striking the NE-SW direction dissected by nearly perpendicular fractures running on NW-SE direction and occupied by basic dyke of basaltic composition. It forms interrupted spots of secondary uranium mineralizations along the contact between the basaltic dyke and the host alkali feldspar granites. The granite around this radioactive spot has reddish pink to brownish red color, hard, massive and silicified. Visible yellow color secondary uranium mineralization occur as thin films staining the joint planes of the alkali feldspar granites and associated with hematitization, silicification and kaolinitization (Fig. 9). 
Anomaly No.2 with 2400 ppm, is also located at the southwestern part of G. Abu Harba alkali feldspar granites. It is documented in large quartz lens along its peripheries with the host alkali feldspar granites. This lens is striking NW-SE direction with dimension of about $10 \mathrm{~m}$. Secondary bright yellow uranium mineralizations appear at the southeastern peripheries of this quartz lens. The uranium mineralization displayed as thin films staining the joint surfaces of the lens and association with hematitization and manganese oxides. This lens displaced by dextral fault striking NE-SW direction and trapping secondary uranium mineralization along joints (Fig. 9).

Anomaly No.3 with 3200 ppm, is located also at G. Abu Harba alkali feldspar granites and characterized by their low topographic level compared with other mineralized occurrences in the study area. It is of lenticular shape and extends for about $1 \mathrm{~m}$ in length and $0.5 \mathrm{~m}$ in width with slightly stretched to the N-S direction. The uranium mineralizations in this occurrence are principally restricted to the intersection zone of $\mathrm{N}-\mathrm{S}$ and $\mathrm{N}-\mathrm{W}$ trending fractures. Visible secondary uranium minerals fill the microfractures of the host alkali feldspar granites and associated with many alterations. These alteration features are commonly represented by strong hematitization staining fracture surfaces around the uranium mineralizations, silicification represented by quartz veinlets as well as dendritic shape of manganese oxides (Fig. 9). There are two another sites of radioactive anomalies but without clearly presence of secondary uranium minerals (Table 3 ).

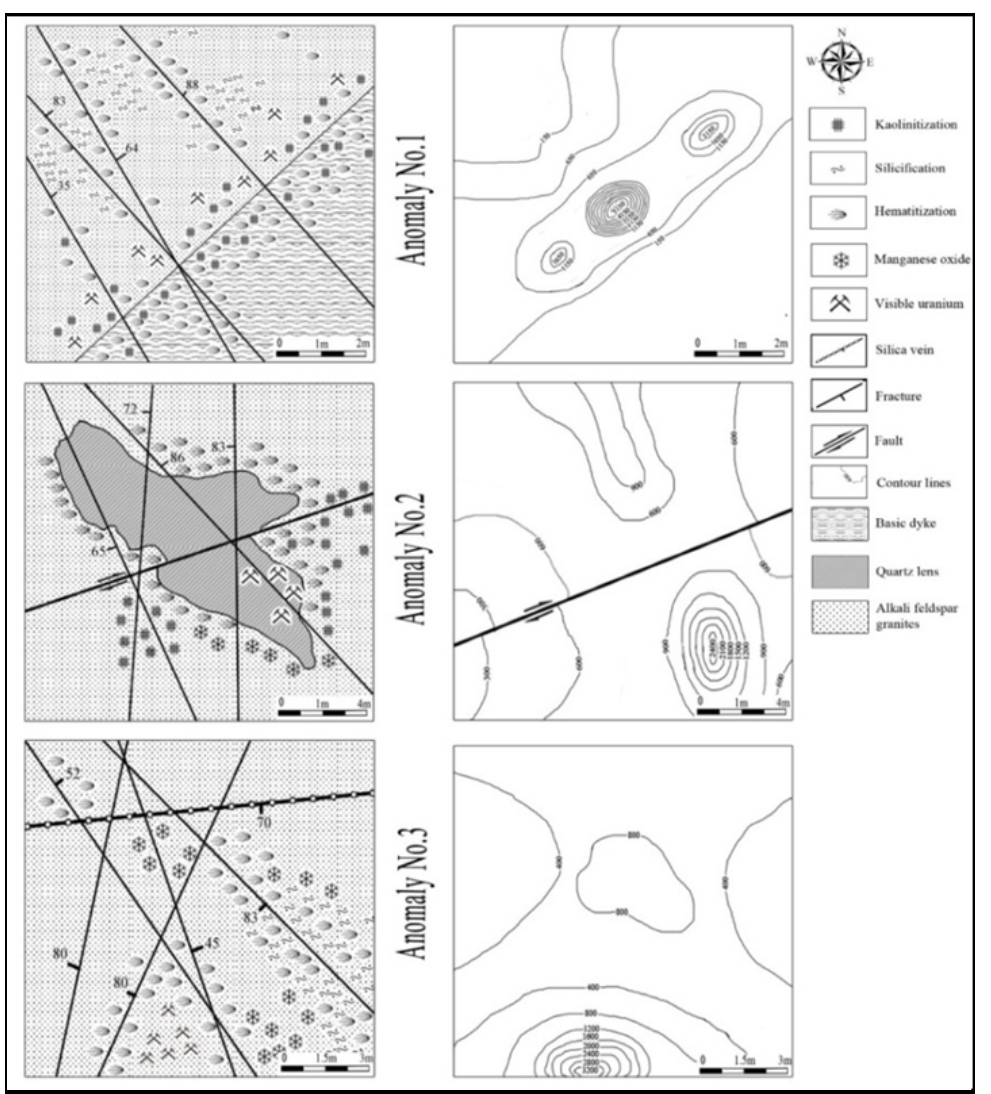

Fig. 9: Geological, structural and contour maps of anomalies.

The mineralogical studies are among the most important studies as they highlight the radioactive minerals and some of the bearing and associating minerals in the studied granites Abu Harba area as they playing an important role in the formation of the uranium mineralizations in the granitic rocks.

Six representative samples collected from different mineralized alkali feldspar granites of G. Abu Harba were crushed and ground to the sieve with size and 60 mesh and washed by distilled water to remove slimes, then dried at $110^{\circ} \mathrm{c}$.

The heavy fraction is separated by bromoform (specific gravity $=2.85 \mathrm{~g} / \mathrm{cm}^{3}$ ) to estimate the heavy mineral content of each size fraction, followed by removal of magnetite by hand magnet. The heavy 
fraction was moreover subjected to magnetic differentiation using the laboratory Frantz isodynamic magnetic separation at different current intensities at $0.2,0.5,1.0$ and 1.5 ampere that occurred in the NMA lab. Several grains of the latter were handpicked from all the obtained sink fractions for quantitative elemental analysis by the Environmental Scanning Electron Microscope (ESEM) which is a Philips Model XL 30 that present also in NMA lab.

Table 3: Statistical analyses of field gamma activity and laboratory measurements for the anomalies in the study area

\begin{tabular}{l|c|c|c|c|c|c|c}
\hline \multirow{2}{*}{ Rock Type } & \multicolumn{3}{|c|}{ Field measurements (cps) } & \multicolumn{5}{c}{ Laboratory measurements (ppm) } \\
\cline { 2 - 8 } & Background & Anomaly & $\mathrm{eU}$ & $\mathrm{eTh}$ & $\mathrm{eTh} / \mathrm{eU}$ & $\mathrm{eRa}$ & $\mathrm{K} \%$ \\
\hline Anomaly No.1 & 530 & 5500 & 1259 & 41 & 0.033 & 1211 & N.D \\
\hline Anomaly No.2 & 600 & 2400 & 159 & 74 & 0.47 & 153 & 6.30 \\
\hline Anomaly No.3 & 550 & 3200 & 876 & 91 & 0.10 & 723 & N.D \\
\hline Anomaly No.4 & 400 & 11500 & 68 & 40 & 0.59 & 52 & 2.93 \\
\hline Anomaly No.5 & 370 & 2400 & 65 & 192 & 2.95 & 34 & 1.21 \\
\hline
\end{tabular}

$N . D=$ not determine

The accessory assemblages of mineralized alkali feldspar granites are mainly composed of zircon, fluorite and iron oxides with rare monazite. Thorite and uranothorite representing the primary radioactive minerals.

The secondary uranium mineralizations are identified in the metasomatized samples of these alkali feldspar granites and composed mainly of uranophane, kasolite and betafite. While sulphides are registered in one mineralized occurrence and represented by barite, galeno-bismutite, cotunnite and galena with rare molybdenite.

\section{Thorite and Uranothorite [(Th, U) SiO4]}

Thorite is a nesosilicate of thorium that crystallizes in the tetragonal system and is isomorphous with zircon and hafnon (hafnium nesosilicate mineral). It represents the most common mineral of thorium and is nearly always strongly radioactive. Thorite grains are ranging in colors from yellow-orange, brownish yellow, brownish black and black. Thorite characterized by vitreous to resinous luster. Thorite is considered an important ore of uranium when it is particularly rich in uranium and often called uranothorite. The hardness is 4-5 in the Moho's scale.

Uranothorite occurs as pale to dark yellow brown grains that are generally translucent to opaque. Uranothorite occurs as pale to dark yellow brown grains that are generally translucent to opaque. They are found as massive grains of anhedral to subhedral and granular form, having a characteristic vitreous or resinous luster.

The Environmental Scanning Electron Microscope (ESEM) microphotographs and EDX analyses reflect the morphological features and chemical composition of thorite and uranothorite (Fig. 6.2\&3). The EDX analysis of thorite confirmed the structural formula of this mineral with Th (64.20\%), Si (14.88\%) and $U(9.85 \%)$. Also the EDX analysis of uranothorite obtained the same structural formula with exceed in uranium percentage where Th $(57.70 \%), \mathrm{U}(21.21 \%)$ and $\mathrm{Si}$ (17.16). Also, minor amounts of REE was reported as substituents for Th (Fig. 10a\&b).

\section{Uranophane $\left[\mathrm{Ca}\left(\mathrm{UO}_{2}\right) 2 \mathrm{SiO}_{3}(\mathrm{OH})_{2} .5 \mathrm{H}_{2} \mathrm{O}\right]$}

Uranophane is also known as uranotile. It is a rare calcium uranium silicate hydrate mineral that forms from the oxidation of other uranium-bearing minerals. Cebron et al., (1993) stated that uranophane is a monoclinic uranyl silicate mineral fairly common in the oxidized zone of most deposits. The grains of uranophane are very soft with pale yellow colors, but some are stained with hematite and become brownish in color. Uranophane grains are occur as massive, radiated or tufted aggregates, as well as, dense microcrystalline masses. Uranophane crystals exhibit poorly developed faces and do not afford good morphological measurements. The luster is waxy or greasy and the streak is yellow. The hardness is 2-3 in the Moho`s scale. 
The back scattered images (BSE) display that the uranophane mineral has a lath crystals with radial fibrous aspect. The EDX analysis of uranophane assured the structural formula of this mineral with $\mathrm{U}$ (66.96\%), $\mathrm{Si}(18.55 \%)$ and $\mathrm{Ca}(9.79 \%)$ (Fig. 10c).

\section{Kasolite $\left[\mathrm{Pb}\left(\mathrm{UO}_{2}\right)\left(\mathrm{SiO}_{4}\right) \cdot \mathrm{H}_{2} \mathrm{O}\right]$}

Kasolite is a hydrated silicate of lead and hexavalent uranium and is the only uranyl silicate with lead as major cation. Rismaite (1977) stated that, kasolite ranks second in abundance after uranophane and beta-uranophane that is occurred in pegmatites and formed under oxidizing conditions. Kasolite is distinguished by its bright colors which are canary lemon, yellow and brown of different intensities. Kasolite minerals are close in their physical properties and morphological features and characterized by their softness to crushing, but they are relatively harder when compared to other secondary uranium minerals. Kasolite is generally distinguished from the other uranium silicates by its crystal habit and luster. The hardness is 4 in the Moho`s scale.

The ESEM microphotographs and EDX analyses reflect the morphological features and chemical composition of kasolite. The back scattered images (BSE) display that the uranophane mineral has a tabular crystals with radial fibrous aspect. The EDX analysis of uranophane assured the structural formula of this mineral with $\mathrm{U}$ (46.29\%), $\mathrm{Pb}(41.55 \%)$ and $\mathrm{Si}$ (8.54\%) (Fig. 10d).

\section{Betafite [(Ca, $\left.\mathrm{U})_{2} \mathrm{Nb}_{2} \mathrm{O}_{6} \cdot \mathrm{OH}\right]$}

Betafite is a mineral group in the pyrochlore super-group which is very rare and occurs as small anhedral grains in the altered granites and distinguished by their dark brown color. Betafite crystals occur as irregular crystals and show dark brown color and greasy luster. The hardness is 5 in the Moho's scale.

The separated betafite crystals were analyzed using ESEM. The EDX analysis of betafite assured the structural formula of this mineral with $\mathrm{U}(60.87 \%), \mathrm{Nb}$ (13.47\%), Ba (12.36\%) and $\mathrm{Si}(6.17 \%)$ (Fig. 10e).

Fig. 10: ESEM image and its EDX spectrum of (a) thorite, (b) uranothorite, (c) uranophane, (d) kasolite, (e) betafite and (f) metamict zircon.

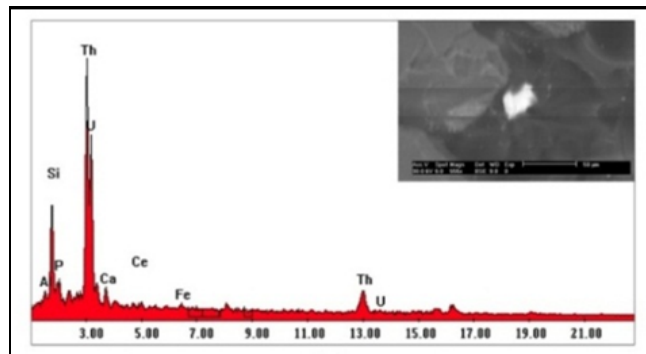

(a)

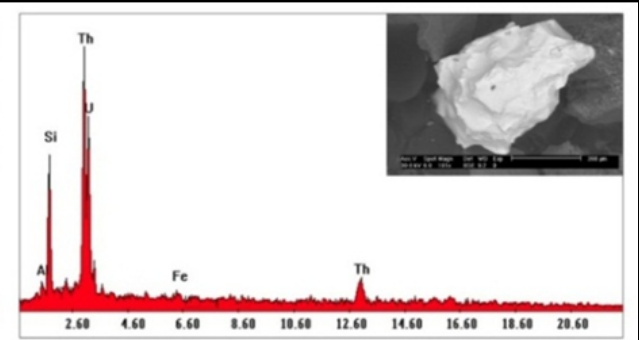

(b)

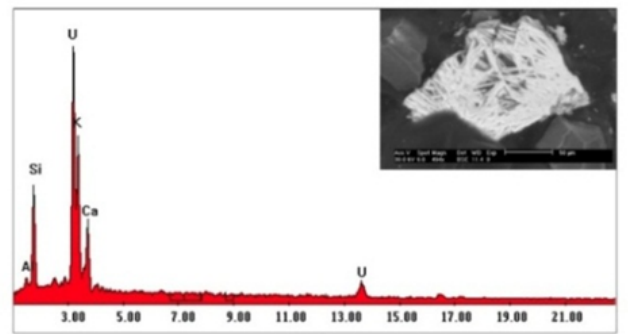

(c)

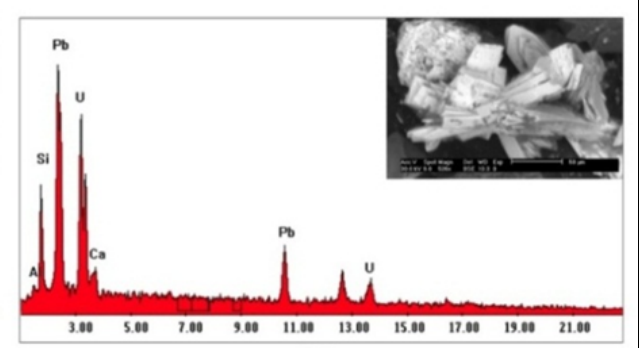

(d)

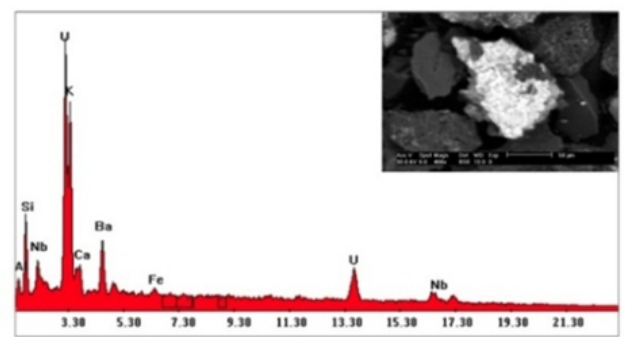

(e)

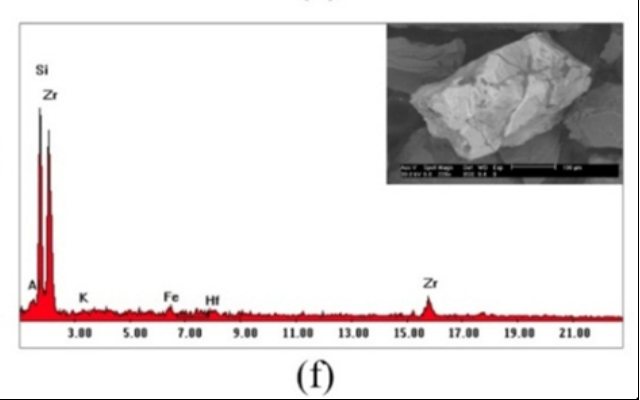




\section{Zircon $\left(\mathrm{ZrSiO}_{4}\right)$}

The radioactive zircon is usually zoned and characterized by metamictization. The explanation of the metamict is that breakdown of the structure in zircon may be due to the presence of radioactive atoms (Deer et al., 1966). Metamictization process causes radial and concentric fractures, which are good pathways for uranium leaching or addition. (Deer et al., 1966) suggested that the ratio of $\mathrm{HfO}_{2} / \mathrm{ZrO}_{2}$ contents is about 0.01 and increases up to 0.04 in metamict zircon. Zircon is found as the most abundant accessory mineral in G. Abu Harba granites, especially in the syenogranites. Zircon crystals are generally colorless and transparent and occur as euhedral prismatic grains. They are characterized by yellow, yellowish red to reddish brown colors and generally sub-translucent to opaque with dull luster. The hardness of zircon is 7.5 in Moho`s scale.

The ESEM image and semi quantitative analysis of zircon picked from the mineralized alkali feldspar granites (Fig. 6.7\&8), shows that it essentially consisting of $\mathrm{Zr}(76.28 \%)$ and $\mathrm{Si}(22.43 \%)$ together with minor amounts of $\mathrm{Hf}(1.29 \%)$. The EDX analysis of the metamictic zircon show $\mathrm{Zr}(65.61 \%)$, $\mathrm{Si}(24.50 \%)$ and $\mathrm{Hf}(4.75 \%)$. Other elements present in small to minor amounts are Al, $\mathrm{K}$ and $\mathrm{Fe}$ (Fig. 10f).

\section{Uranium potentiality of the Abu Harba granites}

Radiometric investigations carried out in the present work revealed that G. Abu Harba area is a good potential prospect for uranium especially at the western alkali feldspar granites of G. Abu Harba, where:

1. The composition of magma played an effective role as concentrating mechanisms, where the concentration of high uranium and moderate to high thorium contents through this pluton reflect a distinct uraniferous magmatic source (Roz, 2001).

2. Nature of hydrothermal solutions is important as a suitable medium for uranium leaching which affected by alteration processes. The effect of the hydrothermal fluids on the alkali feldspar granites especially hematitization, silicification, kaolinitization, flouritization, chloritization and black manganese staining are documented and pervasive in many places, which constitute another guide for locating uranium mineralized occurrences in the studied area.

3. The various rock types in Abu Harba area, display a close relationship between their gamma radioactivity and their lithological characters where the older rocks represented by metavolcanics, metagabbros and Dokhan volcanics usually have lower gamma radioactivity than that of the younger granitic rocks.

4. The alkali feldspar granites display specific characteristics such as the increase of silica and alkalis with appropriate amounts of accessory minerals as barite, fluorite, monazite, zircon and iron oxides which represent a suitable environments for the association of radioactive minerals.

5. G. Abu Harba is cut by sets of faults trending approximately in decreasing order of abundance to ENEWSW, NE-SW, NNW-SSE and E-W directions. These faults represented the major flow channels for hydrothermal fluids which are a favorable locations for fluid flow focusing with its related uranium mineralization.

6. The presence of the Abu Harba area near the Gattarian granites, which represent the most stockpile of uranium in Egypt.

It is concluded that the investigated alkali feldspar granites of G. Abu Harba could represent a good potential source for uranium mineralizations. Thus, searching for granites with similar to these characteristics might be helpful in the exploration for further granites hosting uranium mineralizations in Egypt.

\section{CONCLUSIONS}

Abu Harba granites form a part of big batholith exposed in the study area and extend beyond it. These granites usually bordered by major scale faults and dissected by major and minor scale faults, fractures and joints. Their shape and ridges seem to be related to faulting and fracturing of the area, which also related to regional structures and controlled with vertical movements of the intrusion. 
Uranium mineralizations in G. Abu Harba granites are located at the peripheral western part of alkali feldspar granites which contain highly amounts of silica and alkalis where the gamma radioactivity depends on the degree of acidity, accessory minerals and iron oxides due to their high ability to adsorb uranium from the circulating solutions (Rogers et al., 1978). So it could be concluded that, the mineralizations seem to be lithologically controlled.

On the other hand, the NE-SW lineaments in the study area allowed the hydrothermal solution that bearing uranium minerals to infiltrate upwardly parallel faults and joint sets at the peripheral western part of G. Abu Harba alkali feldspar granites. As the faults are suitable places for the flow of hydrothermal solutions bearing mineralization. So, mineralizations are appear to be structurally controlled.

This study has successfully identified that the alkali feldspar granites of G. Abu Harba is a good potential source of secondary uranium mineralizations. Therefore, there are some recommendations that may be useful in how to determine the amount of radioactive minerals present and how to extract them and their economic feasibility of underestimated such as;

1. Surface and subsurface geophysical studies to determine possible dimensions of mineralized materials.

2. Digging shallow trenches and core analysis to delineate the lateral and vertical continuity of the uranium mineralizations.

3. Microprobe analyses of the accessory minerals included in the alkali feldspar granites to clarify perfectly the mineralogical sites of radioactive minerals.

4. Mineralogical studies of stream sediments collected around Abu Harba pluton in order to attain unknown sites for uranium mineralizations and to test the mobility of the uranium.

5. The full economic benefit of minerals associated with radioactive minerals to cover the expenses of study and extraction.

\section{ACKNOWLEDGMENTS}

The authors would like to thank Dr. Abd El-Basit M. Abd El-Hadi for his efforts and helpful comments and also anonymous reviewers which greatly improved the manuscript.

\section{REFERENCES}

Abd El-Hadi, A. M., (2006): Geological setting and radio-elements distribution in Gabal el Resha-Wadi El Atrash area, North Eastern Desert, Egypt. Msc. Thesis, Fac. Sci. Benha Univ.

Abdallah, A. M., (1999): Geology of Egypt with notes on the geology of nearby Arab countries. Fac. Sci. Cairo Univ., 1999.

Abdel Ghani, I.M., Dardier, A.M., Farag, S.S. and Ibrahim, E., (2003): Petrography and radioelements potentiality of Gabal El-Hurus area, North Eastern Desert, Egypt. Bull. Fac. Sci. Zagazig Univ., 25, 127-148.

Abdel Hamid, A, A., (2013): Mineralogical and geochemical studies of the uranium-bearing granites, Gabal Abu Harba area, North Eastern Desert, Egypt. Ph. D. Thesis, Fac. Sci. Benha Univ.

Abu Deif, A., (1992): The relation between the uranium mineralization and tectonics in some Pan-African granites, West of Safaga, Eastern Desert, Egypt. Ph. D. thesis, Assiut Univ.

Bohse, H., Rose-Hansen, J., Sorensen, H., Steenfelt, A., Lovborg, L. \& Kunzendorf, H., (1974): In Formation of uranium ore deposits (Proc. Symp., Athens, 1974), Vienna. I.A.E.A., 49-90.

Bucher, W. H., (1920): The mechanical interpretation of joints, J. Geol., 28, 707-730.

Cebron, F., Ildefonse, P., and Sichere, M. C., (1993): New mineralogical data on uranophane and Buranophane, synthesis of uranophane. Mineral. Mag., 57, 301-308.

Deer, W. A., Howie, R. A. and Zussman, J., (1966): An introduction to rock forming minerals. Longmans, London. 517.

El Gaby, S., El Nady, O.M., and Khudeire, A., (1984): Tectonic evolution of the basement complex of the Central Eastern Desert of Egypt. Geol. Runds., 73, 1019-1036.

Khamis, (1995): Radioactivity and Structure of Wadi Hammad, North Eastern Desert, Egypt. M.Sc. Thesis, Fac. Sci., Cairo Univ., Egypt. 
Lattman, L. H., (1958): Technique of mapping geologic fracture traces and lineaments on aerial photographs: Photo. Eng., 24, 568-576.

Meshref, W. M., (1990): Tectonic framework. In: R. Said (ed.), The Geology of Egypt, Balkema, Rotterdam, Netherlands, 113-155.

O’Leary, D. W., Fried man, J. D., and Pohn, H. A., (1976): Lineament, linear, lineation, some proposed new standards for old terms: Geological Society of America, 87, 1463-1469.

Rismaite, J., (1977): Mineral assemblages at the, Rabbit Lack uranium deposit, Sastchwan, Geol. Surv. Can., 12, 235 - 246.

Rogers, J. J. W., Ghuma, M. A., Nagy, R. M., Greenberg, J. K., and Fullagar, P. D., (1978): Plutonism in Pan-African belts and the geological evolution of northeast Africa: Earth Planet. Sci. Let., 39, 109-117.

Roz, M. E., (2001): Geology and uranium potentialities in Gabal Abu Harba environs, North Eastern Desert, Egypt. Ph.D. Thesis, Fac., of Sci., Cairo Univ.

Sabins, F. F., (1997): Remote Sensing, principle and interpretation, $3^{\text {ed }}$ edition: Freeman and Company, New York, 494.

Said, R., (1962): The Geology of Egypt. Elsevier. New York, 1962. 15, 377.

Salman, A. B., Shalaby, M. H., Mousa, E. M. M. and Roz, M.A., (2006): Rare earth elements petrogenitic modelling of Gabal Abu Harba granites, North Eastern Desert, Egypt. $7^{\text {th }}$ Inter. Conf. Geochem., Alex. Univ., Egypt, 6-7 Sept. 2006, 1, 59-72.

Stern, R. J. and Hedge, C. E., (1985): Geochronologic and isotopic constraints on late Precambrian crustal evolution in the Eastern Desert of Egypt. Am. J. Sci., 285, 97-127.

Waheeb, A., (2016): Determination of Tectonic Regimes at Gabal Abu Harba Granites and Their Relation to the Distribution of Secondary Uranium Minerals, Northern Eastern Desert, Egypt. Egypt. J. Geol., $60,212-230$.

Waheeb, A., (2017): Detailed Structural Analysis for the Mineralized Shear Zones of G-Ii Uranium Occurrence at Gabal Gattar Younger Granite Northern Eastern Desert Egypt. IJIET, ISSN, 2319-1058.

Youssef, M. I., (1968): Structural pattern of Egypt and its interpretation. Am. Ass. Pet. Geol., Bull., 52, 601-614. 
التراكيب المتحكمة في تمعدنات منطقة أبو حربة، شمال الصحراء الثرقية ’مصر

محمد عبد الرحمن سليمان' و علي فراج عثمان' و فلهم عرابي محمود 'و حامد محمد دويدار 'و حسن إسماعيل الصندولي' ا. هيئة المواد النووية، ص.ب. • به، المعادي، القاهرة، مصر ـ r. قسم الجيولوجيا، كلية العلوم، جامعة عين شمس.

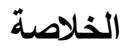

تقع منطقة أبو حربة في شمال الصحراء الثرقية مُمنلةً بالصخور البركانبة المتحولة وبركانبات الدخان وصخور الجابرو

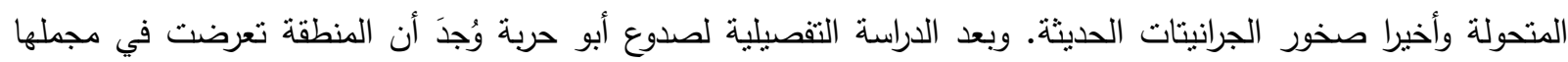
بنوعين من الإجهاد وهمها إجهاد شدً ذو إتجاه NW-SE وإجهاد ضغط ذو لو إتجاه NNE-SSW والذين يمثلا تقريباً إتجاهات

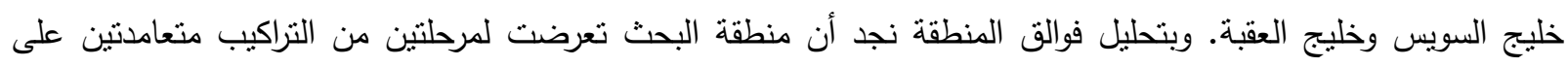

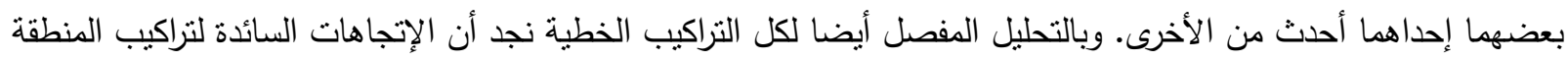
E-W. و NE-SW, ENE-WSW

أثنتت الدراسات المعدنية والتي أُجرِيت على جراينتات أبوحربة الحديثة إحتوائها على بعض من معادن اليورانيوم المشع مُمَتلةً بمعادن اليورانوفين والكازوليت والبيتافيت والمصاحبة لبعض المعادن المشعة الأخرى متل الثثرايت واليورانوثورايت والتي تكونت بهني

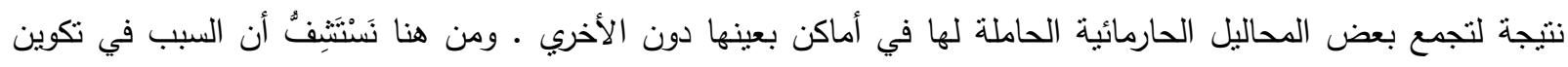
المعادن المشعة في منطقة أبو حربة قد يكون ليثولوجياً بوجودها في صخور جرانيتات الفلسبار القلوية ذات البيئة المناسبة

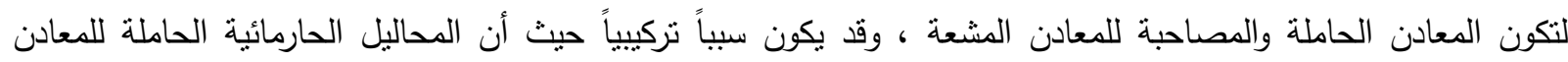
المشعة تتجمع في قنوات سُبيت بتأثير فوالق ذات إتجاهات NE-SW حيث أن الفوالق هي أماكن مناسبة لسريان المحاليل الحارمائية.

ومن كل ماسبق يرى الباحث أن صخور جرانيتات الفلسبار القلوية هي بيئة جيدة لتجمع المعادن الشعة فيها لذلك يقدم الباحث بعضاً من التوصيات للإستفادة القصوى من نواجد هذه التمعدنات والتي تتمنل في مايلي: • إجراء دراسات جيوفيزيقية سطحية وتحت سطحية لمعرفة أبعاد الخامات المتمعدنة. • حفر أبار وخنادق عمودية وأفقية لمعرفة إمتداد التمعدنات داخل الطبقات. • عمل تحاليل مجهرية لإعطاء صورة أفضل للمعادن الحاملة للمعادن المشعة. • عمل دراسات تعدينية للرواسب المحيطة بجبل أبو حربة لمعرفة ما إذا كان هناك آثار لتحرك التمعدنات. • الإستفادة الإقتصادية القصوى من المعادن المصاحبة للمعادن المشعة حتى يتم تغطية نفقات عمليات الدراسة 